\title{
Prasi : Karya Kreatif Estetik Unggulan Bali (Sebuah Studi Teo-Antropologi)
}

\author{
I Nengah Duija \\ Program Pascasarjana Budaya Institut Hindu Dharma Negeri Denpasar
}

nengahduija@yahoo.com

\begin{abstract}
Kebertahanan dan pertumbuhan serta perkembangan seni di Bali secara tidak langsung disebabkan oleh kuatnya sistem keagamaan Hindu yang dianut oleh orang Bali. Keterkaitan seni dan agama tersebut adalah saling mengisi dan saling menguatkan, sehingga kesenian di Bali digolongkan menjadi menjadi seni wali, bebali, dan Balih-balihan. Berdasarkan klasifikasi tersebut, tentu memiliki ragam yang bervariasi pada masing-masing kelompok tersebut. Salah satu ragam seni lukis yang luput dari pengamatan selama ini adalah seni lukis prasi, yaitu seni lukis di atas daun rontal yang digurat dengan pisau khusus (pangrupak) dan dengan bahan dari lontar yang sudah diproses sesuai tradisi pembuatan lontar, serta sebagai tintanya adalah daging buah kemiri (tingkih=bahasa Bali) yang dibakar sampai menjadi arang (adeng=bhs Bali). Tema-tema yang diangkat adalah dari dua epos besar susastra Hindu, yaitu Mahabharata dan Ramayana dengan berbagai variannya. Sebagai hasil analisis menujukkan bahwa karya lukis Prasi yang belum lazim dalam jagat seni lukis umumnya, membuat nilai artistik dari prasi ini sangat luar biasa. Media yang digunakan untuk melukis ukuranya sangat kecil dan harus digurat terlebih dahulu. Nilai-nilai itu di samping sebagai nilai material yang dapat dilihat dengan kasat mata (indrawi), juga nilai-nilai yang terkait dengan kosmologis Hindu (baca:teo-estetik), dan nilai-nilai antropologis tentang kepercayaan pada kehidupan magis dalam kebudayaan manusia Bali. Banyak hal yang dapat disimak dari seni lukis prasi ini sebagai sebuah ekspresi berkesenian orang Bali dan penghayatan pada kekuatan ilahi atau pengejewantahan nilai-nilai ajaran agama Hindu untuk dapat disampaikan sebagai sarana komukikasi kepada seluruh pencinta seni prasi. Oleh karena sang perupa harus memahami betul tentang teknologi tulis-menulis dalam lontar dan mendalami hakikat susastra yang dilukis itu sendiri, dengan kata lain memindahkan wacana sastra dalam guratan lukis prasi.
\end{abstract}

\section{Kata kunci: prasi, karya kreatif unggulan, dan teo-antropologi}

\section{Prasi: Balinese premier creative aesthetic masterpiece (A Theo-anthropology Study)}

The preservation and development of Balinese arts is indirectly caused by the dominance of the Hindu religious system adhered by the Balinese. The relationship between Hinduism and art complement and strengthen each other, which lead to the classification of Balinese arts into the Wali, Bebali, and Balih-balihan. There are also many variations based on said classification. One variant of the fine arts which has seldom been studied is the Prasi drawing, a drawing made on lontar leaf using a special knife (pangrupak), drawn on the media of lontar leaf which has been specially treated according to the lontar writing tradtion. Chared (adeng in Balinese) candlenuts (tingkih in Balinese) is used as the ink source for the drawing. The themes of the drawing are usually based on Hinduism greated sagas, the Mahabarata and Ramayana and the variants. The analysis result shows that since Prasi drawing is quite uncommon in the field of fine arts Prasi then has high artistic values. The media used for drawing very small and the drawing must be etched first hand. Prasi conveys material values which can be enjoyed by our sense, Hindu cosmology (theo-aestetic) and anthropological values regarding the belief of magic in Balinese live. There are many things which can be observed from Prasi as an artistic expression of the Balinese and the embodiment of Godly power or the implementation of Hinduism teaching to be communicated to all Prasi enthusiasts. Therefore, the artist must understand lontar writing technology and also then assence of the literature, in other words the artist must be able to transfer the literature content into Prasi drawing.

Keywords. Prasi, exceptional creative artwork, and theo-antropology

Proses Review : 7 - 25 Januari 2019, Dinyatakan Lolos: 29 Januari 2019 


\section{PENDAHULUAN}

Dinamika kebudayaan Bali dalam berbagai aspeknya saat ini memiliki arah perubahan spiral dengan menggunakan logika "adopsi dan adaptasi" nilai unsur-unsur nilai tradisi menuju nilai-nilai ilmiah, sehingga perkembanganya selaras dengan pola hidup masyarakat Bali itu sendiri. Hal ini ditegaskan oleh Geriya (2010:43) bahwa perkembangan filosofi kosmos, theos, antropos, dan logos merefleksikan arah dan gerak trnasformasi kebudayaan Bali, yang pada hakikatnya tidak bersifat statis. Orientasi filosofi kosmos telah mengkonstruksi pola kebudayaan (pattern of culture) yang harmoni dengan lingkungan dan material. Filosofi theos menumbuhkan pola kebudayaan religius dan bernas dengan nilai spiritual (Mantra,1996:23). Orientals philosophy anatropous secara normatif mengembangkan pola kebudayaan yang humanistik, dan orientasi filosofi logos telah membangun budaya ilmiah.

Pola kebudayaan Bali yang memiliki spirit nilai Agama Hindu telah menjadi kesadaran kolektif masyarakat Bali yang telah diimplementasikan dalam kehidupan sosial mereka dalam bentuk pesidikaraan. Pasidikaraan berasal dari kata sidikara yang berarti kekeluargaan yang bersatu dalam suka dan duka. Ini sebuah konsep kehidupan sosial masyarakat Bali yang terikat oleh nilai kekeluargaan (hubungan geneologis=tunggalan sanggah), juang-kajuang (karena perkawinan), dan ikatan profesi juga masuk dalam klasifikasi pasidikaraan (Warna dkk.1991:646). Nilai-nilai ini setidaknya telah menjadi bagian dari keunggulan kebudayaan Bali. Kemudian ciri-ciri keunggulan suatu budaya sebagaimana Geriya (2010:45-46) menyebutkan sebagai di antaranya adalah (1) memiliki keagungan moral, iman, dan spiritual; (2) kokoh dalam jatidiri dan integritas prilaku; (3) memiliki disiplin, etos kerja dan tanggung jawab; (4) memiliki semangat entrepreneur; (5) memiliki wawasan luas tentang iptek, kearifan, kemajuan adab, serta mampu mewujudkan ke dalam aksi nyata.

Salah satu unsur budaya unggulan Bali adalah seni atau estetika yang memiliki konsep teo-estetik. Istilah teo-estetik adalah konsepsi yang sesungguhnya adalah estetika yang orientasinya pada suprastruktur atau disejajarkan dengan estetika lebur prana yaitu Orientasi seni sebagai jalan "kelepasan" atau lebarnya kawi kecil dengan kawi besar (Granoka,1998; Zoetmulder,1985). Oleh karena seni sebagai sarana dan juga bagian dari laku ritualistik menuju kelepasan jiwa, hal ini yang menyebabkan kesenian Bali memiliki roh yang kokoh dalam kebertahanannya di tengah-tengah arus globalisasi yang sangat pesat mempengaruhi Bali. Analisis yang sama dikemukakan oleh Ida Bagus Mantra (1996:5) berbicara men- genai seni di Bali, karena ada hubungan agama Hindu dengan seni yang tak terpisahkan, hal itu dapat menumbuhkan rasa seni yang sangat mendalam pada masyarakat dalam berbagai bidang, terutama bidang seni pahat, seni gamelan, seni lukis, seni tari, seni hias dan lain-lain. Berpijak pada pandangan di atas, salah satu seni unggulan yang luput dari perdebatan akademik selama ini adalah seni prasi. Menurut Warna dkk (1991:545) Prasi adalah lukisan dalam daun lontar. Kamus Bali-Indonesia . Bandingkan Suwidja (1979:4) Prasi adalah ilustrasi yang dibuat di atas daun rontal maupun di atas kertas gambar dari zaman dahulu hingga sekarang. Ilustrasi juga mempunyai pengertian menghias buku, tulisan atau majalah. Jenis seni atau estetika Prasi ini sebenarnya merupakan sebuah genre seni rupa yang memiliki ciri-ciri dan karakteristik sendiri. Prasi ini tergolong lukisan teknik kering maksudnya dengan teknik kering di sini adalah cara melukisnya dengan bahan-bahan kering, yaitu bahan-bahan yang tidak memakai bahan pencampur air untuk melarutkannya (Supono,1983:17). Bagaimana eksistensi Prasi di Bali sebagai karya kreatif estetik unggulan dalam kebudayaan Bali, maka berikut ini akan dicoba dipaparkan lebih lanjut di bawah ini.

\section{METODE PENELITIAN}

Dalam aspek teoretik seni prasi memiliki substansi dan materi untuk membangunya. Untuk itu digunakan teori Estetika menurut Djelantik (2008:17) yang menguraikan semua benda atau peristiwa kesenian yang mengandung tiga aspek, yaitu: (1) wujud atau rupa (appearance); (2) bobot atau isi (substance); dan (3) penampilan/penyajian (presentation) itu disebut estetika. Dengan demikian estetika yang sesungguhnya berarti teori tentang ilmu pengindraan yang terus mengalami perubahan pengertian yang lebih dapat diterima oleh masyarakat, akhirnya menjadi teori tentang keindahan dan seni. Kemudian ditegaskan kembali oleh Baumgarten yang menekankan secara khusus mengenai penggunaan istilah "estetika" untuk teori tentang keindahan artistic, karena seni merupakan pengetahuan perseptif perasaan yang khusus (Mustopo,1983:102). Penelitian ini merupakan penelitian kualitatif karena yang diteliti adalah karya guratan seni prasi yang bukan untuk menguji dalil atau hukum atau erklarern, tetapi menggunakan logika pemahaman penafsiran atau verstehen. Penelitian ini menggunakan teknik observasi dan wawancara dengan penulis prasi, budayawan, seniman, serta kepuastakaan. Analisis datanya meliputi langkah-langkah : reduksi data, klasifikasi, interpretasi, dan penarikan simpulan.

ANALISIS DAN INTERPRETASI DATA Prasi Sebuah Industri kreatif Estetik Unggulan 


\section{Bali}

Kebudayaan dapat berperan efektif sebagai basis, baik sebagai basis industri kreatif, apabila kebudayaan itu dapat menjalankan sekurang-kurangnya delapan fungsi pokok, yaitu : (1) pembangun roh, etos, dan spirit kreatif; (2) pemberi identitas dan modal budaya; (3) penguatan kelembagaan dan pengorganisasian; (4) pemasok substansi dan produk budya; (5) komunikasi lintas budaya dan komunikasi; (6) nilai tambah; (7) partisipasi, dan (8) keberlanjutan (Geriya,2010:47-48). Spirit kreatif ini menjadi kata kunci dalam membangun dan mengembangkan karya-karya atau produk budaya Bali yang akan menjadi solusi alternatif dalam industri kreatif yang merupakan bagian dari ekonomi kreatif. UK Creative Industries Tasforce (1978) industry kreatif adalah "creative industries are those industries wich have their origin in individual creative, skill and talent, and which have potential for wealth and job creation through the generation and exploitation of intellectual property and content" (Dalam Geriya dkk, 2010:49-50). Dalam kaitanya dengan seni budaya Bali yang penuh dengan kreativitas karya-karya unggulan, Mantra (1996:27) mengatakan seniman-seniman Bali yang mampu menciptakan karya seni yang monumental biasanya memiliki genuine creativity dan untuk bisa menghasilkan karya-karya besar atau "master piece" ia biasanya mempunyai pengetahuan yang luas mengenai nilai-nilai estetika, nilai-nilai tradisi dan teknik mencipta yang matang.

Setiap orang di Bali seakan-akan seorang seniman. Kuli dan pangeran, pendeta dan petani, baik laki-laki maupun perempuan dapat menari, memainkan instrument musik, melukis, atau memahat pada kayu dan batu. Kadang-kadang ditemukan dengan tidak disangka-sangka sebuah desa yang miskin dan hamper roboh memelihara sebuah pura dengan sungguh-sungguh, seperangkat musik atau sekumpulan aktir ulung (Covarrubias,1952:67). Salah satu bentuk karya kreatif estetika yang perlu dipertimbangkan adalah seni lukis di atas daun rontal dikenal dengan istilah prasi. Lukisan prasi menjadi urgen dibahas, oleh karena kreativitas itu sangat spesifikasi tertentu, mulai dari alat, warna, teknik, media, dan sumber gagasan dan lain senagainya. Bagi seniman lukis umunnya, menggoreskan cat basah di atas kanfas pasti sudah lumrah, namun menggurit dengan pengrupak di atas daun rontal memerlukan keahlian khusus mulai dari pemilihan bahan rontal. Itulah hal menarik dan unik dari lukisan guratan pangrupak sebagai genre seni lukis dalam kebudayaan Bali yang kini dikenal luas sebagai prasi. Bentuk-bentuk gambar (lukisan) prasi mengandung tema-tema erotis, peperangan, dan lukisan-lukisan pemandangan alam. Dituangkan melalui guratan-guratan tangan (handsschrift) sebagai hasil dari imajinasi para senimannya untuk melahirkan sebuah karya seni dengan nilai estetika yang tak kalah keindahannya.

Berdasarkan visualisasi, prasi (scratched illustration in palm-leaf manusschripts) itu sebenarnya merupakan sebuah karya seni rupa yang mengambil sumber (babon) karya sastra tertentu, di dalamnya sudah barang tentu mengandung nilai-nilai berkaitan dengan seni maupun sastra. Untuk memahami lebih mendalam memang dibutuhkan analisis lebih akurat tentang prasi tersebut, berkaitan dengan pola-pola (tema) ceritera yang dijadikan objek visualisasi, gambar lukisan, desain dan lain sebagainya. Sebagai sebuah scratched illustration manusschripts tidak hanya menyentuh dari sisi aspek indra penglihatan pada guratan-guratan yang verrukkelijk, namun nampak juga hal-hal yang sangat menggambarkan "kegairahan seksual", karena eksplisit menampilkan lukisan-lukisan (gambaran) erotis. Hal ini menyebabkan dalam masyarakat timbul kontroversi memandang gambar tersebut, di satu sisi cendrung memandang pornografi, sedangkan dipihak lain sebagai ungkapan yang lebih menonjolkan aspek estetika/seninya (Supartha, 1994:93:94). Estetika merupakan suatu istilah yang dikemukakan pertama kali oleh Baumgarten, yang cenderung dipergunakan untuk membicarakan teori tentang keindahan seni (artistic). Akhirnya pengertian estetika berkembang dengan diberi arti sebagai ilmu pengetahuan tentang seni (Mustopo, 1983:97; Waesberghe,2016:5). Mengingat manusia memiliki sensibilitas esthetis yang tak dapat dilepaskan dari keindahan dan manusia membutuhkan keindahan dalam rangka kesempurnaan (keutuhan) hidup pribadinya.

Prasi sebagai karya kreatif estetik dapat dipandang dari aspek teo-antropologi sebagai pandangan manusia Bali terhadap kosmik dengan menempatkan nilai religius sebagai "roh" dari setiap produk budaya Bali. Terlebih seni (baca: prasi) secara teologi merupakan pengejewantahan dari sebuah energy semesta (energy cosmic) yang disebut sang dewa keindahan (kawi-agung) untuk memberikan daya dorong dari dalam setiap seniman atau pragina sang kawi-alit (Zoetmulder, 1990) untuk mampu melahirkan karyakarya besar yang ber-taksu melalui samyoga. Sang kawi adalah seorang hamba pengembara "keindahan" (angdon langö) yang selalu mengolah dan menyegarkan keindahan dalam karyanya (Agastia,1994:52).

\section{Eksistensi Estetika Prasi Sebagai Unggulan Bali}

Sebagai karya kreatif estetik prasi-prasi yang berkembang di Bali sampai saat ini, jika mengacu pada isi ceritanya dapat diklasifikasikan menjadi 4 (empat) tema atau lakon yang berasal dari susastra Hindu, yaitu :

1. Prasi yang berasal dari sastra Kekawin, di an- 
taranya Ramayana, Bharata Yudha, Bomakawya dan Arjunawiwaha. Jenis ini mengambil bentuk wayang klasik, dengan cerita diambil karya kekawain. Khusus untuk daerah Bali-Utara (khususnya Buleleng) dikenal dengan wayang Parba.

2. Prasi yang berasal dari sastra Kidung, di antaranya Jayendriya, Dampati Lalangon, Tantri dan Bramarasangupati, dengan mengambil bentuk wayang Panji, sedangkan ceritanya tetap berasal dari Kidung tersebut.

3. Prasi yang berasal sastra Parwa, di antaranya Adiparwa, jenis ini juga bentuk wayang Parba, sedangkan ceritanya berasal dari Sastra Parwa.

4. Prasi yang berasal dari Kidung Tantri melukiskan tentang pengalaman Raja Aiswaryadala dengan Diah Tantri, selain itu juga mengandung cerita binatang (Suwidja,1979:7-8).

Prasi salah satu jenis naskan lontar di Bali dengan mengambil sumber pada koleksi Prasi pada Museum Bali di Denpasar dan Prasi hasil karya I Nyoman Widana, serta Agus Darmaputra. Koleksi Prasi di museum Bali masih sangat terbatas karena waktunya belum dapat dilakukan secara intensif. Pada kesempatan ini hanya baru 5 (lima) buah prasi yang menjadi fokus bahasan, yaitu : Prasi Mahabharata, Prasi Gajah Mina, Prasi Wong Ngejuk Be, Prasi Arjuna Wiwaha dan Prasi Boma Kawya (Museum Negeri Denpasar, 2012). Prasi hasil karya I Nyoman Widana, yaitu: Prasi Bhatara Gana Embas, Wong Manglende Ring Setra Gandamayu, Ida Sang Prabu Nila Candra Panrestian Bhatara Dharma, Bhatara-Bhatara. Oleh karena itu, seni prasi di Bali ini yang berkembang di masyarakat belum seluruhnya terkoleksi pada Museum Negeri Propinsi Bali.

\section{Aspek-Aspek Estetika Seni Lukis Prasi Bali}

Seniman-seniman yang berkarya dengan berbagai macam media dan gaya telah menciptakan dunia seni. Pengetahuan unsur-unsur seni bagi seniman sangatlah penting dalam menciptakan suatu hasil karya yang bernilai estetik tinggi. Adapun unsur-unsur seni lukis dalam prasi (Supono,1983:31; Jazuli,2014:34-35)) antara lain : (a) Garis; Garis adalah goresan yang dibuat oleh sesuatu alat, seperti: pena, pensil, krayon, lidi dan lain-lainnya. Dalam pengertian ilmu ukur, sebuah garis adalah "sebuah rentetan titik yang tidak ada habisnya. Garis pada umumnya dapat berarti tujuan, orientasi bentuk, gerak dan tenaga. Akibat gerakan, maka yang kurus, yang tajam, linear, dapat mengakibatkan terjadinya bentuk-bentuk yang semuanya secara kolektif hanya termasuk satu tujuan; (b) Warna nilai yang mampu ditampilkan oleh warna sebagaimana juga penampilan suatu garis dapat mengandung aspek estetis dan aspek perlambangan. Di samping nilai-nilai dan makna warna secara universal, yang juga memiliki kaidah-kaidah baku, maka setiap pelukis berusaha menampilkan pribadinya dari pewarnaan. Dari kedua kemungkinan di atas dalam setiap pengucapan seni berusaha menemukan nilai-nilai artistik dan perpaduan warna yang "harmonis" bersifat subjektif; (c) Ruang ruang bersifat tidak terbatas dan tidak terjamah. Ruang larut dalam kegelapan dan ketakberhinggaan. Ruang baru dapat terlihat kalau ada bentuk dan batasan karena alam atau perbuatan manusia. Ruang dalam seni lukis ada yang Tri Matra (karya seni yang dapat dilihat dari segala penjuru arah dan memiliki tekstur), dan Dwi Matra (karya seni yang dapat dilihat dari tampak depan dan samping saja); (d) Tekstur tekstur ialah sifat permukaan suatu benda, baik itu nyata maupun semu. Suatu permukaan benda itu mungkin, kasar, halus, lunak, dan bisa saja licin. Tekstur ada dua antara lain tekstur nyata (bila permukaan suatu benda diraba secara fisik nyata kasar), dan tekstur halus sebaliknya.

\section{Aspek Penampilan Prasi}

Bahan-bahan yang dipergunakan untuk membuat lukisan Prasi, di antaranya, adalah daun rontal/lontar (bahasa Latin : Borossus Flabellife L), dan buah Kemiri (Bhs. Bali: tingkih dan Bhs. Latin : Aleurites Mollucana). Kedua bahan inilah yang sesungguhnya sangat dibutuhkan untuk bisa menghasilkan suatu karya estetik yang disebut prasi. Selain kedua bahan yang disebutkan di atas, kadang-kadang juga digunakan warna pada tepi daun rontal, sehingga nampak lebih rapi. Biasanya cara memberikan warna itu dengan menggunakan cat yang dapat dibeli pada toko bangunan untuk lebih praktis dalam penyelesaiannya dan bahan tersebut lebih mudah didapat. Masyarakat sudah agak jarang membuat warna itu secara tradisional, mengingat dalam proses pembuatan bahan tersebut membutuhkan waktu yang cukup lama untuk lebih jelasnya mengenai kedua bahan tersebut diungkapkan secara lebih rinci dalam uraian di bawah ini.

Pertama, daun rontal atau bhs. Bali ental, bagi masyarakat Bali sering diucapkan dengan lontar yang merupakan bentuk metafisis dari kata rontal. Kata rontal itu meliputi dua patah kata, yaitu "ron" (artinya daun) dan "tal=ental" (artinya nama pohonnya) yang termasuk bahasa Jawa Kuna yang diperkirakan sudah ada sebelum jaman raja Balitung, awal abad ke-10 Pohon rontal ini juga disebut pohon siwalan, karena disebut pohon siwalan serumpun dengan jenis pohon palem ( $\mathrm{palm} / \mathrm{palmyra}$ ) dengan ciri-ciri karakteristik kehidupan pohon ini yang sangat menonjol, yaitu tumbuhnya liar dan sangat lamban serta memiliki perkembangan kehidupan yang sangat panjang sampai ratusan tahun lebih dan khusus untuk di daerah Bali pohon ini nampaknya banyak tumbuh/hidup pada lahan yang kering dan kritis. Betuk daunnya menyerupai kipas yang sangat lebar dan besar, seh- 
ingga sering juga disebut pohon kipas.

Menurut Suwidja (1979:4), lontar (bahasa latin : Borossus Flabellife L) yang dipergunakan untuk membuat prasi (lukisan bergambar pada daun lontar), dipilih yang khusus untuk menggambar. Kemudian daun rontal yang dipergunakan sebagai alat tulis prasi dipilih daun lontar yang memiliki tingkat kehalusan yang dibedakan menjadi tinggi, sedang, dan kasar. Daun rontal yang dipergunakan sebagai alat untuk menggambar prasi, dipilih yang seratnya halus mulus supaya lukisan yang terpatri pada daun rontal nampak lebih bagus serta lebih mudah mengerjakannya. Selanjutnya mengenai tumbuhan pohon rontal ini, di daerah Bali umumnya masyarakat mengklasifikasikan menjadi 3 (tiga) jenis yaitu :

a. Rontal (ental) Taluh jenis rontal ini mempunyai daun yang lebih lebar dan panjang serta serat-seratnya lebih halus. Jika ditulis, maka tekanan pada alat pengerupak sangat sedikit menimbulkan suara, mengingat goretan yang ditimbulkan tidak terlalu keras

b. Rontal (ental) Goak, jenis rontal ini daunnya lebar dan panjang serta memiliki serat-serat yang agak kasar. Jika ditulis, maka tekanan pada pengerupak menimbulkan suara yang lebih keras, karena menggoretnya agak keras

c. Rontal (ental) Kedis, jenis rontal ini tidak memiliki daun lebar maupun panjang sehingga tidak mencukupi bila dipergunakan untuk tulisan tertentu. Memang jenis rontal ini hampir sama dengan jenis rontal Taluh yang juga memiliki daun dengan serat-serat yang sangat halus.

Di antara ketiga jenis rontal yang disebutkan di atas, maka daun rontal yang bisa digunakan untuk membuat prasi, yaitu jenis rontal Taluh dan rontal Kedis, mengingat jenis daun lontar ini mempunyai serat-serat yang halus, sehingga goretannya tidak membutuhkan tekanan yang keras, begitu pula suaranya tidak nampak keras saat melakukan goretan. Hasilnya juga nampak jauh lebih baik, walaupun untuk jenis rontar Kedis ini memang panjangnya tidak mencukupi atau kurang panjang.

Daun rontal yang masih muda dipetik dari pohonya, terlebih dahulu disortir (dipilah-pilah) untuk mendapatkan jenis daun rontal yang berkualitas. Selanjutnya dijemur sampai kering di bawah terik sinar matahari selama sehari, sesudah kering baru lidinya dilepas (dipisahkan) dari daunnya kemudian dipotong dengan gunting dengan perkiraan panjang tertentu, untuk membuat bagian-bagian yang tidak bermanfaat sebagai alat tulis atau gambar. Selanjutnya dilakukan pemilihan (disortir) kembali untuk mendapatkan daun rontal yang berukuran 4 X $60 \mathrm{Cm}$ sebagai rontal tulis maupun gambar. Namun daun rontal yang digunakan untuk prasi ukurannya tidak ada yang baku, sehingga diketemukan berbagai variasi mengenai ukuran tersebut. Misalnya untuk panjang ada diketemukan $30 \mathrm{Cm}, 45 \mathrm{Cm}, 59 \mathrm{Cm}$ dan lain sebagainya, begitu pula mengenai lebarnya ada $3,5 \mathrm{Cm}$, dan $4.0 \mathrm{Cm}$. Untuk menghilangkan zat hijau daunnya, dapat dilakukan merendam di dalam air selama 3 sampai 4 hari. Harus dibersihkan dengan sikat yang dibuat dari serabut kelapa (bahasa Bali : sepet) untuk menghilangkan bintik-bintik, berupa telur belalang, telur serangga dan kotoran lainnya.

Jika sudah dicuci bersih daun rontal tersebut dijemur kembali selama sehari. Perlu dilakukan perebusan dengan air yang sangat panas (mendidih) untuk merubah daun rontal yang kaku (keras) agar menjadi lemas (tidak kaku) sekaligus memberi warna kuning kemerah-merahan (bahasa Bali : gading). Caranya merebus daun rontal tersebut supaya hasilnya baik, terlebih dahulu digulung dengan rapi, kemudian dimasukkan ke dalam periuk yang airnya telah mendidih serta air ini sudah dicampur dengan zat pewarna tertentu, seperti daun liligundi (Vitex Trifolia L), Gambir secukupnya dan Kunyit Warangan (Curcumalonga $L$ ). Lama merebus daun rontal ini hingga air mendidih sampai 2 kali (bahasa Bali ; duang luaban), selanjutnya baru diangkat dari periuk langsung dijemur kering, bila daun rontal yang dijemur terlalu kering, sehingga sulit untuk meratakan, maka perlu ditaruh ditempat yang berembun di waktu malam hari (bahasa Bali : damuhin/dayuhin). Bila sudah lemas baru dilakukan penyusunan secara rapi lembar demi lembar lalu dijepit (press) dengan sebuah alat spesial yang dipergunakan untuk itu (bahasa Bali : blabag) selama kira-kira 10 hari. Kalau waktunya sudah cukup maka daun rontal yang dijepit (press) tadi dikeluarkan, selanjutnya diukur mengenai lebar dan panjangnya berdasarkan ukuran-ukuran ( $\mathrm{mal}$ ) yang sudah jadi atau mencontoh selembar daun rontal yang ukurannya sudah ada. Kemudian dilanjutkan dengan membuat lobang sebanyak 3 buah menurut ukuran dan tempatnya. Jarak lobang yang satu dengan yang lainnya diatur sedemikian rupa. Pembuatan lobang sebanyak 3 buah itu meliputi ke-2 bagian ujung dari daun rontal dan di tengah-tengahnya. Jarak lobang diatur sedemikian rupa, supaya jangan lobang yang ditengah-tengah betul persis jaraknya dengan lobang kiri (pertama) dan lobang kanan (ketiga). Harus ada perbedaan jarak lebih kurang $2 \mathrm{Cm}$, yang menunjukkan bahwa garis disebelah kanan selalu lebih panjang daripada garis disebelah kiri. Begitu pula garis disebelah kiri ini harus selalu merupakan pangkal daripada daun rontal tersebut (Suwidja,197:5).

Kedua, buah kemiri (bahasa Bali, Tingkih dan latinnya :Aleurites Mollucana) hanya berfungsi sebagai tinta, yaitu menghitamkan bekas-bekas goretan dari 


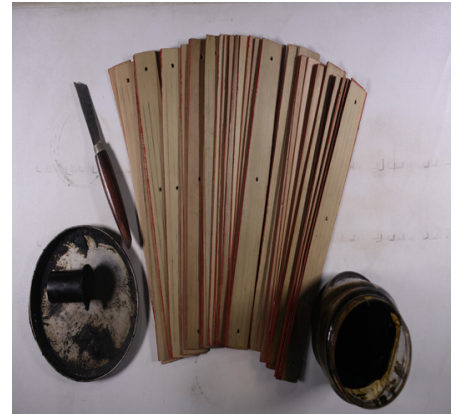

Gambar 1. Bahan-bahan Pembuatan prasi (Sumber: Koleksi I Nyoman Widana, 2017)

pengerupak yang berfungsi sebagai alat tulis maupun gambar, sehingga nampak jelas huruf atau tulisan termasuk juga gambar bisa dilihat mata dengan jelas. Ciri karakteristik daripada buah kemiri (bahasa Bali, tingkih dan latinnya : Aleurites Mollucana) tempurungnya sangat keras dan daging buahnya agak lunak serta berminyak. Pohon ini tumbuhnya sangat rindang, mengingat daunnya yang sangat lebat. Pohon Kemiri ini bisa menjulang tinggi kira-kira sampai mencapai puncaknya antara 20-30 meter dan batangnya bisa berdiameter 1 meter. Termasuk tanaman berakar tunggal yang bisa tumbuh subur dimana saja dan termasuk tanaman musiman, hanya berbuah sekali setahun. Pada putik daunnya tumbuh bunga berwarna putih mirip seperti daunnya yang agak lebih kecil, kemudian tempat putik bunga untuk menjadi calon buah. Dalam satu buah maksimal berisi dua biji, bila sudah tua buah ini sangat mudah jatuh.

Daging buah Kemiri warnanya putih dan juga kandungan minyaknya cukup tinggi, lalu proses selanjutnya dibakar dengan menggunakan peralatan khusus, biasanya digunakan sebuah mangkuk kecil yang terbuat dari bahan sejenis seng. Cara membakar daging buah Kemiri ini memang mirip dengan cara menggoreng sampai dagingnya hancur serta warnanya berubah menjadi hitam disertai dengan minyaknya yang cukup banyak. Jadi daging buah kemiri ini yang sudah terbakar berwarna hitam disertai dengan minyaknya, dilumatkan sampai hancur, didinginkan dan ditaruh di atas meja, lalu diambil dengan menggunakan jari tangan. Selanjutnya dipoleskan pada daun rontal yang telah ditatah atau digambar maupun ditulis dengan alat pengerupak. Kemudian bekas-bekas goretan dari alat pengerupak tersebut supaya nampak dengan jelas atau bisa dilihat dengan mata, maka harus dipoles dengan daging buah Kemiri tadi. Daging buah kemiri tersebut dapat berfungsi sebagai tintanya daripada goretan-goretan alat pengerupak pada daun rontal, apakah itu tulisan, gambar, lukisan dan lain sebagainya.

Alat yang dipergunakan untuk menulis atau menggambar di atas daun rontal disebut "pengutik" atau

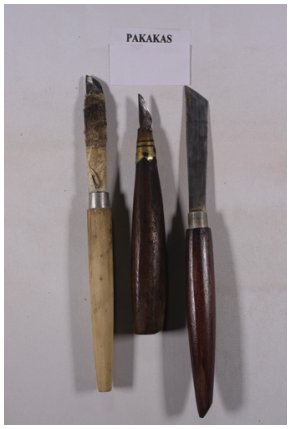

Gambar 2. Peralatan Pembuatan Prasi, (Sumber: Koleksi I Nyoman Widana, 2017)

"pengerupak", yaitu sebuah pisau kecil yang secara khusus dibuat dari besi baja. Dibagian ujungnya runcing dan berbentuk segitiga dengan maksud agar dapat membuat tebal atau tipisnya huruf (goretan). Masyarakat di Bali, terutama yang memiliki keahlian (profesionalisme) dalam membuat tulisan maupun menggambar di atas daun rontal (tukang prasi), mengenal 3 (tiga) jenis "pengerupak" yaitu :

a. Pengerupak untuk menulis, "pengerupak untuk menulis ini lebarnya kurang lebih 1,5 $\mathrm{Cm}$ dan panjangnya menurut selera dari si pemakai, tetapi pada umumnya panjang itu hanya sampai 15 Cm.

b. Pengerupak yang dipergunakan untuk menggambar. Untuk jenis ini sangat berbeda dengan "pengerupak" yang dipergunakan untuk menulis, lebarnya lebih kecil, yaitu hanya meliputi $0,5 \mathrm{Cm}$ dan panjangnya sama seperti "pengerupak" untuk menulis, agar bisa menghasilkan garis yang sama (konstan).

c. Pengerupak yang dipergunakan untuk memotong. Jenis "pengerupak" ini, kalau dilihat dari segi betuk ukurannya, baik itu mengenai besar, lebar maupun panjang tidak terbatas.

Peralatan lain yang diperlukan antara lain :

1. Pensil, yang dipergunakan untuk membuat sket (desain) sebagai suatu rancangan gambar pada daun rontal

2. Lap yang dipergunakan untuk membersihkan tinta hitam yang dipoleskan pada daun rontal, supaya kelihatan gambar itu lebih rapi, bersih dan artistik

3. Meja gambar, yaitu sebuah meja yang dipergunakan sebagai tempat menggambar di atas daun rontal (prasi)

4. Peralatan untuk membuat lobang pada daun rontal, alat penjepit atau pres (bahasa Bali : Blagbag) untuk mengencangkan daun rontal. Serut, alat untuk meratakan tepi daun rontal, supaya lebih rapi pada bagian tepi, maka diperlukan amplas atau daun bamboo. Di samping untuk merapikan, juga berfungsi untuk menghaluskan.

Mendesain suatu gambar di atas daun rontal, bukan- 
lah suatu pekerjaan yang mudah dihadapi bagi seniman prasi. Sebagaimana telah dijelaskan di atas, bahwa melukis maupun menggambar di atas daun rontal merupakan pekerjaan yang sangat rumit. Karena yang harus diperhatikan adalah perubahan bentuk gambar yang menyesuaikan dengan ruang (space) pada daun rontal tersebut. Di sini peranan desain diwujudkan melalui bentuk sket yang dibuat dengan pensil. Di dalam membuat sket gambar prasi di atas daun rontal, ada beberapa hal penting yang harus diperhatikan bagi seniman prasi supaya hasil karya seni itu bisa menampilkan yang indah, rapi dan menarik bagi masyarakat pencita seni. Hal-hal tersebut merupakan kaidah komposisi yang ditemukan dalam dunia melukis, yang meliputi : (1) proporsi, yaitu setiap ruang, warna, bidang, bentuk dan tekstur harus mendapat bagian tempat yang seimbang di atas bidang;(2) balance, yaitu keseimbangan dalam pembagian bidang, ruang dan warna ; (3) irama, yaitu menempatkan warna, garis, bentuk, ruang, tekstur dalam gerak yang continue dan luwes akan kelihatan bagi irama yang syahdu dan harmonis ; (4) pusat pandang, yaitu sebuah karya harus ada sebuah objek yang menjadi senteral dan pusat perhatian, walupun letaknya tidak mesti ditengah ; (5) kontras, yaitu adanya perbedaan yang jelas antara latar belakang dan objek sentralnya ; (6) unity, yaitu adanya kesatuan antara warna yang satu dengan yang lainnya maupun objek-objeknya ; dan (7) harmoni, yaitu gabungan dari semua unsur di atas, haruslah akur dan tampak seia sekata tanpa adanya tumpang tindih (Sugiantara,1999:14; Jazuli,2014:35).

\section{Aspek Teknologi Pembuatan Prasi}

ditinjau dari proses menggambar prasi dapat dikatagorikan menjadi 3 (tiga) tahap, yaitu : (1) tahap mempersiapkan bahan-bahan meliputi daun rontal yang biasanya dipilih jenis daun rontal "taluh" (telur). Karena daun ini dianggap paling baik, memiliki serat-serat daun, bila ditulisi atau menggambar di atas daun ini hasil goresan dari alat "pengerupak" sangat baik. Bahan pewarna yang dibuat dari biji buah Kemiri (buah tingkih=Bhs.Bali) yang dibakar hingga menjadi arang (adeng $=$ Bhs.Bali), selanjutnya diulek (ulig=Bhs.Bali) dan dicampur dengan minyak kelapa murni (lengis tandusan=Bhs.Bali) hingga menjadi hitam yang berwarna pekat (mangsi ; dan (2) alat "pengerupak" berupa sebuah pisau kecil yang dibuat dari besi baja, dimana pada bagian ujungnya sangat runcing dan berbentuk segitiga. Kedua hal ini sudah dijelaskan pada bagian di atas, namun juga diperlukan peralatan yang lain, yaitu berupa meja tulis, supaya bagi seniman prasi bila melakukan aktivitasnya dengan baik, artinya bisa menulis maupun menggambar di atas daun rontal dengan hasil karya seni yang sangat mengagumkan bagi masyarakat yang menghayatinya. Bila sebuah peralatan tersebut sudah lengkap, baru bisa melakukan kegiatan menulis maupun melukis (mengguratkan) pada daun rontal dengan menggunakan sebuah alat "pengerupak". Cara menggambar prasi ini mula-mula diambil sehelai daun rontal yang sudah diproses dan siap untuk ditulis. Berarti ukurannya sudah tepat benar dengan telah memperhatikan ujung dan pangkalnya, bagian sebelah kiri dan bagian sebelah kanan. Selain itu, juga harus diperhatikan tiga lubang dari rontal itu, kemudian barulah diadakan perencanaan atau melakukan sket yang akan digambar.

Terlebih dahulu dalam perencanaan membuat gambar harus membuat konsepnya di atas kertas dengan pensil dan jaman dahulu konsepnya dibuat di atas batu tulis dengan anak batu tulis. Bilamana para seniman telah selesai mewujudkan gagasan pikirannya yang dituangkan dalam konsep sesuai dengan keinginannya maupun seleranya, maka barulah digoreskan dengan "pengerupak". Naskah-naskah berupa kakawin maupun kidung yang akan digambar, terlebih dahulu dibaca dari permulaan. Selanjutnya bagi seniman prasi memikirkan dan sekaligus menafsirkan serta memilah kata-kata yang akan ditulis. Setelah lukisan atau gambar terklasifikasi dengan baik dan tidak perlu untuk dirubah, maka barulah dipoleskan tinta (seperti telah digoreskan di atas). Jadi, pada bekas-bekas dari goresan "pengerupak" ini tinta tersebut akan masuk ke dalamnya, dan sisa-sisa tinta yang masih bertebaran pada saat dipoleskan di atas daun lontar dibersihkan atau dihapus dengan lap yang akhirnya tinta hanya melekat pada daun lontar yang tergores saja. Hal ini untuk mendapatkan gambar yang hitam di atas daun rontal (seni prasi).

Secara realitas nampaknya para seniman prasi di Bali, tidak sebanyak seniman seni lukis. Karena kemungkinan proses menggambar prasi kerjaannya cukup rumit, di samping memerlukan kesabaran yang tinggi serta tidak boleh tergesa-gesa. Begitu pula halnya dalam menyelesaikan karya seni prasi, jangan sekali-kali ingin menyelesaikan pekerjaannya dengan cepat. Mengingat setiap goresan dan garis-garisnya haruslah betul-betul mendukung dan terpadu sebagai sebuah hasil gambar. Tidak ada goresan yang terbuang atau tidak berguna. Para seniman harus mampu memproyeksikan lukisan berukuran besar di atas daun rontal menjadi lukisan berukuran kecil, serta diusahakan agar tidak ada goresan yang ketinggalan. Karena memang dituntut dalam menggambar prasi sangat mendetail sifatnya. Mengingat tuntutan yang disertai dengan kecermatan itu, diharapkan akan menghasilkan gambar yang harmonis dan indah. Selain itu, harus juga diperhatikan faktor dalam dan dangkalnya dari goresan "pengerupak" harus sesuai dengan keinginan dan keindahan dari hasil karya seni prasi tersebut. Namun yang perlu diperha- 


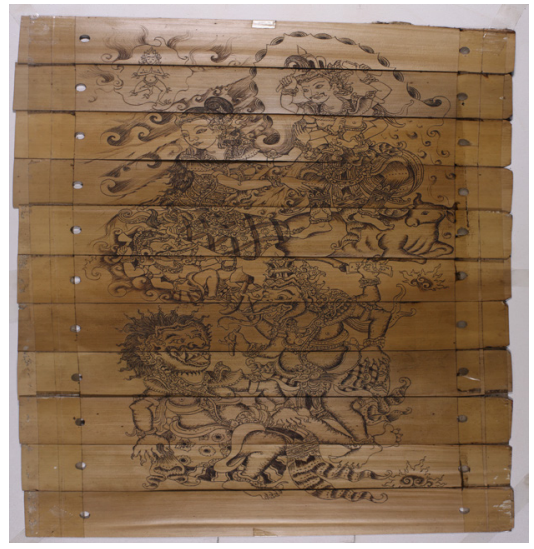

Gambar 3. Prasi Bhatara Gana Embas, (Sumber: Koleksi I Nyoman Widana)

tikan dalam lontar atau prasi tradisional Bali, diketemukan istilah Grantang base, yaitu setiap kalimat atau bait dilukiskan dengan gambar. Kata "grantingan" yang berarti panjang dan "base" berarti bahasa. Sebuah kekawin, apabila memakai grantang base, maka disela-sela bait dari kekawin tersebut dibubuhi dengan bahasa Bali. Grantang base ini, juga dapat diartikan dengan mencari arti kata atau memiripkan arti kata tersebut dengan kata lain dan kadang kala atau memiripkan arti kata tersebut dengan kata lain dan kadang kala mengenai dengan arti. Begitu pula dalam mengambil bait kata, kadangkala yang diambil yang terpokok saja. Ini berarti apa yang ditulis dalam rontal, baik itu seni sastra maupun lainnya, belum tentu dalam wujud penggambarannya sama dengan kata-kata terebut. Keadaan ini, sudah barang tentu sangat berbeda dengan ilustrasi komik, majalah, koran, dan lain sebagainya. Faktor ini yang menyebabkan keunikan dari sebuah kekawin menggunakan grantang base, seperti diungkapkan dalam kekawin Smarandhana (Winasa,1992 :28-29).

\section{Prasi Bhatara Gana Embas}

Dalam prasi Bhatara Gana Embas (embas Bhs. Bali=lahir) di bawah ini diambil tokoh-tokoh tertentu, seperti Bhatara Siwa, Dewi Uma, Bhatara Gana dan seorang Raksasa.

\section{Prasi Wong Manglende Ring Setra Gandamayu \\ Prasi Wong Manglende Ring Setra Gandamayu (orang mempraktekkan ilmu hitam=leak di kuburan) di bawah ini juga diambil beberapa tokoh seperti : Rangdeng Dirah, dengan para Waksirsanya. \\ Prasi Ida Sang Prabu Nila Candra Panrestian Bha- tara Dharma}

Prasi Ida Sang Prabu Nila Candra Panrestian Bhatara Dharma di bawah ini juga mengabil beberapa tokoh, seperti Ida Sang Prabu Nila Candra, Ida Bhagawan Antasinga, Prabu Kresna, Panca Pandawa.

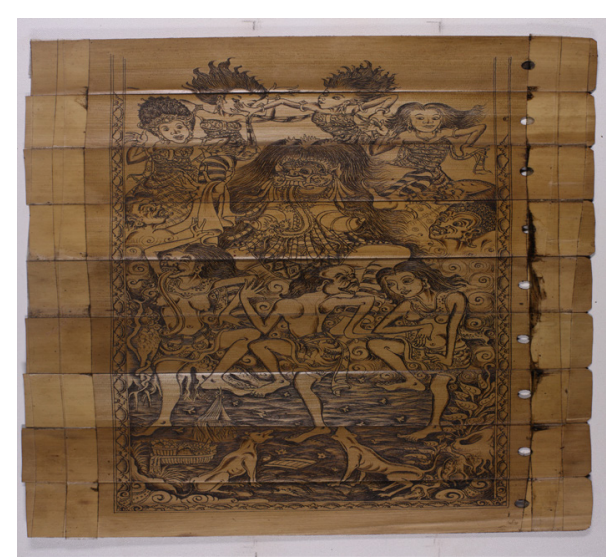

Gambar 4. Prasi Wong Manglende Ring Setra Gandamayu, (Sumber: Koleksi I Nyoman Widana)

\section{Aspek Nilai Teo-Antro Estetika Prasi Bali}

Peranan seni seni dalam dalam masyarakat sangat penting, maka secara garis besar memiliki fungsi, (1) seni sebagai sarana upacara; (2) seni sebagai hiburan; (3) seni sebagai tontonan; dan (4) seni sebagai media pendidikan (Jazuli,2014:49-50). Menurut Waesberghe (2016:20) sesungguhnya manusia selalu bertindak berdasarkan empat hal, (1) Etika (baik-buruk, boleh-tidak boleh; (2) Logika (daya nalar tentang sesuatu yang benar); (3) Estetika (esensi keindahan); dan (4) Mistika (esensi keagamaan). Suatu hal yang menarik bahwa secara prinsip fungsi seni dalam kehidupan manusia khususnya Bali adalah sebagai sarana upacara. Itulah yang menyebabkan seni di Bali sangat terkait dengan agama Hindu (teo-estetik).

I Gusti Bagus Sugriwa (1952:22) menyatakan bahwa kesenian Bali atau seni budaya suku Bali-Hindu yang hidup bergolak sampai sekarang, pada hakikatnya adalah anak atau cabang ranting dari agama Hindu Bali. Kesenian dengan agama ini mempunyai hubungan yang amat erat pada umumnya tidak dapat dipisahkan satu sama lainya. Tegasnya jika agama Hindu Bali itu musnah dari nusa Bali ini, tak dapat tiada lambat-bangatnya kesenian Bali-Hindu yang meliputi seni sastra, seni nyanyi, seni tari, seni ukir, seni rupa dan lukis dan bunyi-bunyian pun akan turut parama satia membunuh dirinya. Sebaliknya bila kesenian Bali-Hindu itu hilang, mungkin pula agama Hindu-Bali itupun gaib juga. Ini sebagai sebuah tesis tentang sebuah perspektif teo-estetik dalam memahami Bali dalam ranah seni dan budaya sebagai sebuah sikap religius orang Bali

Di samping itu, dalam konsep estetika Hindu di Bali khususnya terdapat dalam konsep tiga wisesa : satyam (kebenaran), siwam (kesucian), sundaram (keindahan). Hal ini dikamsudkan untuk mencapai ruang estetika metafisika, agar kita mampu meneropong roh kita yang terhanyut oleh keindahan (langö) dengan objek ritual magis, yaitu penyucian sang diri 


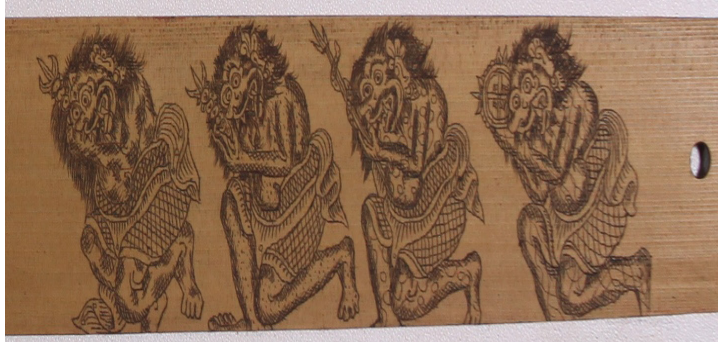

Gambar 5. Prasi Watek Detya

(Sumber: Koleksi I Nyoman Widana)

(katharsis). Di sanalah estetika telah masuk pada ruang kesunyian (suwung). Di sanalah jiwa telah lebar menyatu dengan dewa keindahan yang abadi (Granoka,1998:28). Oleh karena dalam estetika Hindu yang dipentingkan adalah sebuah dialektika estetik yang selalu menempatkan kebenaran itu suci dan indah, kesucian itu harus benar dan indah, serta keindahan itu harus suci dan mengandung kebenaran.

Jika dilihat dan disimak gambar-gambar prasi di atas. Estetika unggulan yang potensial menjadi nilai peradaban Bali adalah bahwa lukisan prasi memiliki orientasi kesadaran pada dua hal, yaitu: (1) kesadaran teo-kosmik, dimana nilai vertical dari prasi itu bersifat religious-magis-antropologis. Tema-tema yang diangkat memiliki keterkaitan dengan sistem budaya dan sistem kegamaan Hindu di Bali. Penggambaran para dewa-dewa (lahirnya Bhatara Gana-Ganesa) memiliki kekuatan teo-estetik yang luar biasa, menurunkan suatu pesan moral kepada manusia Bali bahwa ada kekuatan semesta yang menjadi kendali nilai material yang ada di jagat raya ini. antropologis-magis adalah pandangan budaya Bali tentang kekuatan alam (prasi manglende ring setra) (baca: religi), yaitu ilmu hitam yang disekanl dengan ilmu leak atau ngeleak (black-magic). (2) kesadaran akan logika teknologi dalam penggarapan prasi sebagai bentuk kreativitas seni lukis yang tidak biasa dilakukan oleh. Kepaduan antara gagasan (sumber nilai acuan), struktur karya/wujud, dan media/skill sungguh menjadi nilai artistic yang unggul dibandingkan seni lukis umumnya.

\section{SIMPULAN}

Berdasarkan uraian tersebut di atas, maka dapat ditarik beberapa poin simpulan dari lukisan prasi sebagai berikut :

Prasi adalah lontar bergambar (ilustrasi), digoreskan dengan "pengrupak" berupa pisau khusus untuk menggambar di atas daun rontal. Jenis-jenis prasi meliputi : Veda, Agama, Wariga, Itihasa, Babad, Tantri dan Lelampahan. Bahan-bahan yang dipergunakan untuk mewujudkan karya seni prasi ini, antara lain : daun rontal sebagai ruang atau tempat (space) yang

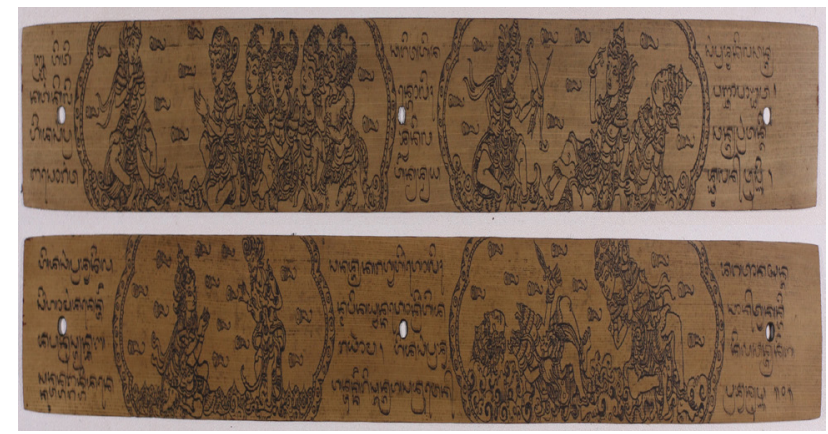

Gambar 6. Prasi Ida Sang Prabu Nila Candra Panrestian Bhatara Dharma, (Sumber: Koleksi I Nyoman Widana)

digunakan untuk menggambar dan biji buah Kemiri sebagai bahan untuk membuat tinta, serta dicampur dengan minyak kelapa murni (lengis tandusan=bhs. Bali).

Alat-alat yang dipergunakan dalam proses pembuatan gambar (ilustrasi) di atas daun rontal, seperti alat pres atau jepit (bahasa Bali:blagbag), serut (alat untuk meratakan sisi lontar), amplas, daun bambo, alat untuk membuat lobang dan "pengrupak" yang berbentuk segitiga pada bagian ujungnya lancip dan tajam dibuat dari bahan baja berukuran kira-kira $1,5 \mathrm{Cm} \times 15 \mathrm{Cm}$ dengan tebal $1,5 \mathrm{~mm}$, sebagai alat untuk membuat goresan pada daun rontal (lontar). Termasuk juga alat yang serupa dengan ini sebagai pemotong daun rontal dan sebagai alas untuk menggambar biasanya digunakan meja tulis. Dalam menggambar atau membuat ilustrasi di atas daun rontal (prasi) ada beberapa tahapan yang harus dilalui, yaitu : (a) gagasan atau ide tentang karya seni seni prasi yang ingin dikejawantahkan oleh seniman prasi melalui perenungan ; (b) menyiapkan peralatan alat gambar seperti daun rontal dan pengerupak dan bahan-bahan yang dibutuhkannya ; (c) membuat sket (rancangan atau disain) gambar yang dibuat dengan pensil atau sejenisnya ; (d) apabila sketnya sudah pasti sesuai dengan estetikanya, baru dilanjutkan dengan menggunakan "pengerupak" untuk membuat goresan yang lebih dalam sebagai tempat meletakkan tinta hitam ; dan e) kalau semua goresan yang telah dibuat dari "pengerupak" sudah dianggap baik, baru dipoles dengan tinta hitam dan selanjutnya dibersihkan dengan lap.

Nilai-nilai estetika yang dapat disimak dari prasi-prasi itu manyangkut nilai vertical dan nilai horizontal. Vertikal dimaksudkan bahwa tema-tema yang diangkat terkait dengan kosmologi Hindu sebagai sebuah system nilai teo-estetik. Sedangkan horizontal berkaitan dengan sstem budaya Bali, yaitu kesadaran terhadap kekuatan semesta dan kelakukan manusia Bali terhadap hal-hal yang bersifat magis. Munculnya pandangan orang Bali terkait dengan ilmu hitam yang dikenal sebagai ilmu leak atau pengleakan 


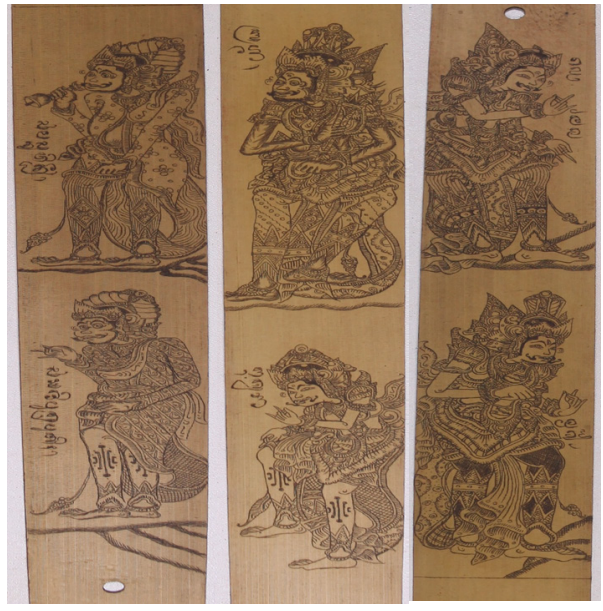

Gambar 7. Prasi Bhatara-Bhatara, (Sumber: Koleksi I Nyoman Widana, 2017)

(baca: pengiwa-penengen).

\section{DAFTAR RUJUKAN}

Agastia, I.B.G.1980."Geguritan Sebuah Bentuk Karya Sastra". Paper Sarasehan Sastra Bali, Pesta Kesenian Bali ke 2 Art Cantre Denpasar.

Agastia, I.B.G.1984. "Cerita Tantri Dalam Kasusastraan Bali" Widya Pustaka, Denpasar: Fakultas Sastra Unud.

Agastia, I.B.G.1994. Kesussastraan Hindu Indonesia (Sebuah Pengantar). Denapasar: Yayasan Dharma Sastra.

Arsana, Supono.1983. Dasar-Dasar Seni Lukis. Departemen Pendidikan Dan Kebudayaan Didektorat Jenderal Pendidikan Dan Menengah.

Aryandini Sumaryoto, Woro. 2002. Wayang dan Lingkungan. Jakarta : Universitas Indonesia

Astra, I Gede Semadi.2004. " Revitalisasi Kearifan Lokal Dalam Upaya Memperkokoh Jati Diri Bangsa”. Dalam Politik dan Identitas Etnik.Editor I Wayan Ardika dan I Nyoman Darmaputra. Denpasar: FS Unud dan Bali Mangsi Press.

Ayatrohaedi.1986. Editor. Kepribadian Budaya Bangsa. Jakarta: Pustaka Jaya.

Bagus, I Gusti Ngurah, 1975. Kebudayaan Bali, Manusia dan Kebudayaan di Indonesia, (Koentjaraningrat, Ed) Jakarta : Jembatan.

Bandem, I Made.2001. Wayang Wong. Yogyakarta: Bali Mangsi.
Djelantik. 2008. Estetika Sebuah Pengantar. Jakarta : Masyarakat Seni Indonesia.

Hinzler, 1993. Balinese Palm-Leaf Manuscrif. Leiden University Press.

Katalog Lontar Fakultas Sastra Unud, 1988. Fakultas Sastra Universitas Udayana : Denpasar

Covarrubias, Miquel.1952. "Seni dan Seniman". Dalam Majalah Kebudayaan Indonesia Nomor Bali. Jakarta: Lembaga Kebudayaan Indonesia.Hal.67.

Geriya, I Wayan dkk.2010. Kebudayaan Unggul. Inventori Unsur Unggulan sebagai Basis Kota Denpasar Kreatif. Denpasar: Bappeda.

Gie, The Liang. 1983. Garis-Garis Besar Estetika (Filsafat Keindahan). Yogyakarta: Penerbit Supersukses.

Jazuli.M.2014. Sosiologi Seni Edisi 2. Pengantar dan Model Studi Seni. Yogyakarta: Graha Ilmu.

Kayam, Umar.1981. Seni, Tradisi, Masyarakat. Jakarta: Sinar Harapan.

Mantra, Ida Bagus.1996. Landasan Kebudayaan Bali. Denpasar: Yayasan Dharma Sastra.

Mardiwarsito.L.1990. Kamus Jawa Kuna - Indonesia. Ende Flores: Nusa Indah.

Monmon, Sudarma.2014. Antropologi Untuk Komunikasi. Jakarta: Mitra Wacana Media.

Pigeaud, Theodore. 1967-1981. Literature of Java, The Hague : Martinus Nijhoff.

Plyte.1912. Dampati-Lalangon. Koninklijk Bataviaasch Genootschap Van Kunstenen Wetenschappen (KBG).

Plyte.1967. Prasi tentang Tantri dari Bali (binatang) Poerbatjaraka, R.Ng.1933, NitiçastraOud Javaansche tekst met Vertaling. Bandung: A.C. NIX.

Robson, S.O.1978. Pengkajian Sastra Nasional dan Sastra-Sastra Klasik Indonesia. Bahasa dan Sastra, Th. IV. No. 6.

Suastika, I Made, 1996. Tradisi Penulisan Lontar di Bali, Dalam Majalah Lontar. No : 1 Tahun I. Denpasar : Pusdok Propinsi Bali. 
Suastika, I Made, 1997. Bimbingan Teknis ke Arah Peningkatan Kualitas dan Profesionalisme Penulis Lontar Prasi di Desa Tenganan-Karangasem, Denpasar : Lembaga Pengabdian pada Masyarakat, Unud.

Sugriwa, I Gusti Bagus.1952. "Seni Budaya Hindu Bali". Dalam Majalah Kebudayaan Indonesia Nomor Bali. Jakarta: Lembaga Kebudayaan Indonesia. Hal.17.

Sulastin-Sutrisno.1981. Relevansi Studi Filologi. Pidato Pengukuhan Guru Besar dalam Bidang Ilmu Filologi Fakultas Sastra Universitas Gajah Mada.

Supartha, I Made. Erotisme dalam Prasi Bali.Makalah tidak terbit

Sulistyorini, Dwi.2015. Filologi Teori dan Penerapanya. Malang: Madani.

Sutrisno, Mudji dan Christ Verhaak.1993. Estetika Filsafat Keindahan. Yogyakarta: Kanisius.

Suwdija, I Ketut.1979. Mengenal Prasi, Singaraja : Gedong Kirtya

Teeuw, A. 2017. Sastra dan Ilmu Sastra. Pengantar Teori Sastra. Jakarta: Pustaka Jaya.

Warna dkk.1991. Kamus Bali Indonesia. Denpasar: Dinas Pendidikan Dasar Provinsi Bali.

Waesberghe, Smith van.2016. Estetika Musik, Editor. Sunarto. Yogyakarta: Thafamedia.

Winasa, Putu, 1992. Prasi Karya I Gusti Bagus Sudiasta dari desa BungkulanSingaraja Bali, Skripsi Sarjana (S1). Yogyakarta : Fakultas Seni Rupa dan Desain, Institut Seni Indonesia.

Widana, I Nyoman.2012.Prasi Salah Satu Naskah Kuno di Bali. Makalah tidak terbit.

Zoetmulder, P.J.1995. Kamus Jawa Kuna- Indonesia. Bekerjasama dengan S.O Robson. Penerjemah Darusuprapta dan Sumarti Suprayitna. Jakarta: PT. Gramedia Pustaka Utama. 